\title{
Linear Programming on Bread Production Using Uncertainty Approach
}

\section{Adamu Wakili}

Department of Mathematics Faculty of Science, Federal University Lokoja, Nigeria

Email: wakili.adamu@fulokoja.edu.ng

\author{
Article History \\ Received: 3 October, 2021 \\ Revised: 19 December, 2021 \\ Accepted: 28 January, 2022 \\ Published: 2 February, 2022 \\ Copyright (C) 2022 ARPG \\ \& Author \\ This work is licensed under \\ the Creative Commons \\ Attribution International \\ (c) $(4)$ \\ CC BY: Creative \\ Commons Attribution License \\ 4.0
}

\begin{abstract}
Linear programming is applied to bread production and the raw materials for the research were collected from the bakery industry in Lokoja which were clearly identified. The paper took into account three types of bread with estimated profits and the problem was formulated from the collected data. The formulated problem was parameterized into parametric linear programming and run using the developed algorithm of linear programming The result obtained indicates that profit is made at $\mathrm{d}$ different values of the parameter, $\mathrm{t}$, leaving the company the choice of any profit it wants to get.
\end{abstract}

Keywords: Linear programming; Optimize; Parameter; Objective function; Limitations; Estimate and interval.

\section{Introduction}

A new war-related projects demand attention and spread resources all over the glove. Many theorems have been developed in linear programming and explored their applications in recent times. Linear programming model is one of the best technique of managing scare resources for optimal production globally, particularly during high cost of production, economic crisis and srecession $[1,2]$. A company's endurance in the competitive market closely depends on its stability to produce the highest quality products at the lowest possible cost [3]. There is no doubt that there are limited resources at the disposal of every organization and as a result of this, managers are forced with decision to choose the best means of managing the scare resources using linear programming in order to maximize profit [4].

In recent time, manufacturing industries at all levels are faced with the challenges of producing goods of right quality and quantity on time and more especially at minimum cost and maximum profit for the survival and growth. Thus, this demands for an increase in production efficiency of the industry [5]. In today business competition is getting tighter and harder, with more and more companies growing. This condition causes many companies to be at their forefront of their fields. In reality every company must be able to develop and improve performance to achieve effectiveness and efficiency. With this new ideas are needed to bring the business world into a more advanced direction so that it can keep up with the increasingly tight competition [6-9].

\section{Methodology}

The use of linear programming tools and MATLAB algorithm to obtain optimal cutting plane, They employed the use of two software tools to solve Mathematical program for optimization of sheet metal cutting plane. Isah, et al. [9]; Junaid and Mukhtar [10] focused on linear programming for achieving production mixed optimization in terms of the product identification and the right quality in paint production for better profit and optimum firm performance.

\section{Data Collection and Formulation}

The data used for this work were collected from Ostrich Bakery Lokoja and the amount of raw materials are; sugar, flour, yeast coconut-flavour, pineapple flavour and soybean-oil for daily production of the three different type of bread (pineapple, coconut and butter bread) and the profit per each type of the bread produced depended on the availability of the raw material and the required flour. The quality of flour available is $200 \mathrm{~kg}$ each unit of coconut bread requires $0.2 \mathrm{~kg}$ of flour, each unit of pineapple bread requires $0.24 \mathrm{~kg}$ of flour and each unit of butter bread requires $0.14 \mathrm{~kg}$ of sugar.

Total amount of sugar available is $150 \mathrm{~g}$, each unit of coconut bread requires $0.14 \mathrm{~kg}$ of sugar $0.14 \mathrm{~g}$ of sugar, each unit of pineapple bread requires $0.2 \mathrm{~g}$ of sugar and each unit of butter bread requires $0.1 \mathrm{~g}$ of sugar. 


\subsection{Yeast Available for Production}

The total amount of yeast available is $20 \mathrm{~kg}$, each unit of coconut bread requires $0.02 \mathrm{~kg}$ of yeast, each unit of of pineapple bread requires $0.02 \mathrm{~kg}$ of yeast and each unit of butter bread requires $0.02 \mathrm{~kg}$ of yeast.

\subsection{Salt Available for Production}

The total amount of salt available is $18 \mathrm{~kg}$. Each unit of coconut bread requires $0.0011 \mathrm{~g}$ of salt, each unit of pineapple bread requires $0.0105 \mathrm{~g}$ of salt and each unit of butter bread requires $0.00017 \mathrm{~g}$ of salt.

\subsection{Soy-Bean-Oil Available for Production}

The total amount of soy-bean-oil available is $10.01 \mathrm{~g}$. Each unit of coconut bread requires $0.0157 \mathrm{~g}$ of soy-bean oil, each unit of pineapple requires $0.021 \mathrm{~g}$ of soy-bean oil and each unit of butter bread requires $0.00981 \mathrm{~g}$ of soybean oil.

\subsection{Coconut Flavour Available for Production}

The total amount of coconut flavour available is $20 \mathrm{~g}$. Each unit of coconut bread requires $0.0 \mathrm{~g}$ of coconut flavour, each unit of pineapple bread requires $0 \mathrm{~g}$ of coconut flavour and each unit of butter bread requires $0 \mathrm{~g}$ of coconut flavour.

\subsection{Pineapple Flavour Available for Production}

The total amount of pineapple flavour available is $20 \mathrm{~g}$. Each unit of coconut bread requires $0 \mathrm{~g}$ of pineapple flavour, each unit of pineapple bread requires $0.02 \mathrm{~g}$ of pineapple flavour and each unit of butter bread requires $0 \mathrm{~g}$ of pineapple flavour.

\subsection{Butter Flavour Available for Production}

The total amount of butter flavour available is $200 \mathrm{~kg}$. Each unit of coconut bread requires $0.001 \mathrm{~kg}$ of butter flavour, each unit of pineapple bread requires $0.001 \mathrm{~kg}$ of butter flavour and each unit of butter bread requires $0.09 \mathrm{~kg}$ of butter flavour.

Profit per unit type of bread produced is as follows: each unit of coconut bread made a profit of $\$ 25$ - $\$ 30$, each unit of pineapple bread made a profit of $\$ 30-\$ 35$ and each unit of butter bread made a profit of $115-\mathrm{N} 20$.

Table-1. Production requirements

\begin{tabular}{l|l|l|l|l}
\hline Raw Material & $\begin{array}{l}\text { Coconut } \\
\text { bread/g }\end{array}$ & $\begin{array}{l}\text { Pineapple } \\
\text { bread/g }\end{array}$ & $\begin{array}{l}\text { Butter } \\
\text { Bread/g }\end{array}$ & $\begin{array}{l}\text { Total availability of } \\
\text { raw material }\end{array}$ \\
\hline Flaour & 0.2 & 0.24 & 0.14 & 200 \\
\hline Sugar & 0.14 & 0.2 & 0.16 & 150 \\
\hline Yeast & 0.02 & 0.02 & 0.02 & 20 \\
\hline Salt & 0.0011 & 0.00105 & 0.00017 & 18.5 \\
\hline Soybean oil & 0.0157 & 0.021 & 0.0098 & 10 \\
\hline Coconut flavour & 0.02 & 0 & 0 & 20 \\
\hline Pineapple flavour & 0 & 0.02 & 0 & 20 \\
\hline Butter & 0.001 & 0.001 & 0.09 & 50 \\
\hline
\end{tabular}

\subsection{Problem Formulation}

Let $x_{1}$ be the quantity of coconut bread to be produced.

$x_{2}$ be the quantity of pineapple bread to be produced.

$x_{3}$ be the quantity of butter bread to be produced.

So the parametric linear programming is as below:

As the formulated problem has uncertainty (estimates) components in the objective function, it has to be parameterized and generates solutions from the specified values of the parameter, $t$, within a closed interval.

$\operatorname{Max} Z=(30+5 t) x_{1}+(35+3 t) x_{2}+(20+4 t) x_{3}$

$$
\begin{array}{ll}
0.2 x_{1}+0.24 x_{2}+0.14 x_{3} \leq 200 & \\
0.14 x_{1}+0.2 x_{3}+0.16 x_{3} \leq 150 & \\
0.2 x_{1}+0.02 x_{2}+0.02 x_{3} \leq 20 & \\
0.0011 x_{1}+0.00105 x_{2}+0.00017 x_{3} \leq 18.5 & \leq 10 \\
\text { s.t } \quad 0.0157 x_{1}+0.021 x_{2}+0.0098 x_{3} \leq 10 & \leq 20 \\
0.02 x_{1} & \leq 20 \\
0.0011 x_{1}+0.001 x_{2}+0.09 x_{3} & \leq 50 \\
& x_{1}, x_{2}, x_{3} \geq 0
\end{array}
$$


Table-2. Results of computation

\begin{tabular}{l|l|l|l|l}
\hline $\mathbf{t}$ & $x_{1}$ & $x_{2}$ & $x_{3}$ & Value Z(N) \\
\hline 0 & 335.57 & 0 & 551.827 & 21103.658 \\
\hline 0.1 & 335.57 & 0 & 551.827 & 21547.355 \\
\hline 0.2 & 335.57 & 0 & 551.827 & 21991.055 \\
\hline 0.3 & 335.57 & 0 & 551.827 & 22434.754 \\
\hline 0.4 & 335.57 & 0 & 551.827 & 22878.451 \\
\hline 0.5 & 335.57 & 0 & 551.827 & 23322.150 \\
\hline 0.6 & 335.57 & 0 & 551.827 & 23765.848 \\
\hline 0.7 & 335.57 & 0 & 551.827 & 24209.547 \\
\hline 0.8 & 335.57 & 0 & 551.827 & 24653.246 \\
\hline 0.9 & 335.57 & 0 & 551.827 & 25096.945 \\
\hline 1 & 335.57 & 0 & 551.827 & 25540.645 \\
\hline
\end{tabular}

\section{Result and Analysis}

The results obtained in table 2 of results of computation showed that Coconut bread $\left(x_{1}\right)$ will. be 336 units, pineapple bread $\left(x_{2}\right)$ will not be produced and butter bread $\left(x_{3}\right)$ will produced 552 units to make the profit of $\$ 21103.658$ to $\$ 25540.645$ depending on the value of the parameter, $t$. The results give the decision maker (the manager) the opportunity to choice the values of $t$ that will him the desire results within the uncertainty. The estimated parameter $(t)$ covers all the unknown circumstances that may arise during or after production. This means the production of pineapple bread has no effect on the profit the bakery.

\section{References}

[1] Adejo, L., Lekan, O. K., and Shagari, J. N., 2013. "Application of linear programming for optimum production planning in maidabino investment Nigeria limited, katsina." International Journal of Operational Research in Management Social Science and Education, vol. 66, p. 76.

[2] Anieting, A. F., Ezugwa, V. O., and Ologun, S., 2013. "Application of linear programming technique in determination of optimum production capacity." JOSR. Journal of Mathematics, vol. 5, pp. 62-.65.

[3] Woubante, G. W., 2017. "The optimization problem of product mix and linear programming applications." International Journal of Innovation, Management and Tevchnology, vol. 2, pp. 24-31.

[4] Balogun, O. S., Jolayemi, E. T., Akingbade, T. J., and Muazu, H. G., 2012. "Use of linear programming for optimal production in a production of line in coca cola bottling company, Ilorin." International Journal of Engineering Research and Application, vol. 2, pp. 2004-2007.

[5] Okolie, P. C., Dara, J. E., Sinebe, J. E., and Iwenofu, C. O., 2013. "Optimization of processing data time for stephens bread industries owerri, imo state, Nigeria." International Journal of Multidisciplinary Sciences and Engineering, vol. 4, pp. 230-240.

[6] Banbang, S. A., Rosida, R. M., Auggun, M. M., Cindy, D. M., and Yulita, L., 2018. "Pprofitt optrimization using simplex method on home industry bintang bakery in sukarame bandar lampung." In IOP Conference Series Journal of Physics. p. 1155.

[7] Ibitiye, O., Atoyebi, K. O., Genevieve, K., and Kadiri, K., 2015. "Entrepreneur decision making process and application of linear programming technique." European Journal of Business, Economics and Accounting, vol. 3, pp. 1-5.

[8] Iheagwara, A. I., Opara, J., Esemokumo, P. A., and Lebechi, J. I., 2014. "Application of linear programming problem on niger mills company plc, calabar." International Journal of Innovation and Research in Educational science, vol. 1, pp. 105-114.

[9] Isah, U. K., Norhairul, H. B., and Imran, A. J., 2011. "Optimal production planning for ICI Pakistan using linear programming and sensitivity analysis." International Journal of Business and Social Science, vol. 2, pp. 206-212.

[10] Junaid, A. A. and Mukhtar, H. S., 2010. "Development of optomal cutting plan using linear programming tools and matlab algorithm." International Journal of Innovation, Management and Technology, vol. 1, pp. 483-492. 